\title{
Societal acceptance of carbon capture and storage technologies
}

\author{
Klaas van Alphen*, Quirine van Voorst tot Voorst, Marko P. Hekkert, Ruud E.H.M. Smits \\ Department of Innovation Studies, Copernicus Institute for Sustainable Development and Innovation, Utrecht University, \\ P.O. Box 80115, NL 3508 TC, Utrecht, The Netherlands
}

Received 11 December 2006; accepted 8 March 2007

Available online 20 April 2007

\begin{abstract}
For the actual implementation of carbon capture and storage (CCS) technologies, societal support is a crucial precondition. This paper describes an extensive study on the acceptance of CCS by stakeholders in the Netherlands and explores one of the determining factors in the acceptance of CCS by the lay public, i.e. the way the Dutch press perceives and portrays CCS. The stakeholder analysis shows that there is a positive attitude towards CCS by industry, government, and environmental NGOs, provided that the conditions they pose on the deployment of CCS are met. The content analysis of Dutch news articles conveys that the media portrayal of CCS is - to a certain extent - a balanced reflection of the way CCS is perceived by the stakeholders. Both analyses show that the concerns about CCS have not overshadowed the main promise that CCS is part of the solution to climate change. However, the current negative aspects of CCS as raised by different stakeholders and the media will remain if no action is taken. Therefore, the conditions posed on the use of CCS, as well as the actions required to meet these conditions, could function as a proxy for the 'societal voice', articulating the most important issues concerning the future acceptance of CCS technology.
\end{abstract}

(C) 2007 Elsevier Ltd. All rights reserved.

Keywords: Public opinion; Stakeholders' attitudes; Media content analysis

\section{Introduction}

Despite the fact that many countries strive for the stabilization of greenhouse gas concentrations in the atmosphere at a level that prevents dangerous interference with the climate system (UN, 1997), most scenarios portray a substantial increase in the anthropogenic emissions of carbon dioxide for the decades to come. The world's primary energy supply will continue to be dominated by fossil fuels until at least the middle of this century, and a portfolio of mitigation measures is required to provide the emission reductions needed to achieve stabilization (EEA, 2004; IPCC, 2001). This notion has led to a growing interest among policy makers around the world in the technology of carbon dioxide capture and storage (CCS) as a means of reducing carbon dioxide emissions, while continuing to make use of (domestic) fossil fuel resources and infrastructure (Gough and Shackley, 2006).

\footnotetext{
*Corresponding author. Tel.: + 31302536369 ; fax: + 31302532746 .

E-mail address: k.vanalphen@geo.uu.nl (K. van Alphen).
}

CCS is a technology that comprises the separation of carbon dioxide from industrial and energy related sources, transport to a storage location (e.g. saline aquifers and depleted hydrocarbon fields), and long-term isolation from the atmosphere. Some characteristics of this technology may cause societal resistance upon actual implementation, like the possible leakage of carbon dioxide from the storage reservoirs and its impact on the local environment (IPCC, 2005).

Societal acceptance is widely recognized as an important factor influencing the successful development and diffusion of new technologies (OECD, 2003; Reiner et al., 2006). Illustrative examples of societal opposition hindering or even stopping the actual implementation of planned projects involving energy technology can be found in relation to nuclear power (OECD, 2001; Pickett, 2002; Surrey and Huggett, 1976; van der Pligt, 1992) and, more recently, in wind energy programs (Devine-Wright, 2005; Devlin, 2005; Kaldellis, 2005).

Many decision makers now realize that a better understanding of potential societal responses preceding the 
implementation of CCS projects is desirable to effectively design public policy for this technology (Dietrich and Schibeci, 2004; Shackley et al., 2006). Consequently, it is useful to study these possible response strategies in the early development stages of CCS technology, in order to overcome possible impediments created by various societal groups (de Best-Waldhober et al., 2006; Itaoka et al., 2006).

Societal acceptance of CCS includes the response of both the lay public and stakeholders. We define stakeholders as agents with a professional interest in CCS. Hence, stakeholders can include industry, non-governmental organizations (NGOs), governments and research institutions. The issues concerning CCS are quite different for the lay public compared to the stakeholders. One of the reasons for this is that the latter nearly always have a defined agenda or set of preferred policy objectives in mind when evaluating CCS, whereas the lay public does not have an a priori viewpoint (de Coninck et al., 2006).

In fact, the few studies on public perceptions of CCS indicate that this technology is largely unknown to the general public (Ashworth et al., 2006; Curry et al., 2004; de Best-Waldhober and Daamen, 2006; Itaoka et al., 2004; Palmgren et al., 2004; Shackley et al., 2004; Sharp et al., 2006). Moreover, a study by Daamen et al. (2006) shows that the current public opinion on CCS options, assessed by traditional questionnaires, is unstable and affected by small amounts of information given to the respondent. These uninformed opinions are weak indicators for predicting future public acceptance of CCS technology and by this a source of uncertainty for policy makers. Instead, marketing efforts of stakeholders and information given by the media ${ }^{1}$ have a major influence on how CCS will be perceived by the general public (Huijts, 2003; Zaller, 1992).

Therefore, we argue that stakeholders can play a double role in the development of CCS technology. On the one hand, they have a direct influence on the implementation of CCS projects, because of their professional interest in the technology. On the other hand, they can indirectly influence this process because of their ability to shape the public opinion by the way they proclaim their perception on CCS technology into society (Terwel et al., 2006). Despite this important (double) role of stakeholders, they (especially environmental NGOs) are hardly involved in CCS programs, nor are they subject of scientific studies on the societal acceptance of CCS (de Coninck et al., 2006; Mander and Gough, 2006).

The relation between the attitudes of stakeholders and the opinion of the general public is far from simple, as the media to a large extend control what kind of communica-

\footnotetext{
${ }^{1}$ Although people receive information concerning the aspects of complex technologies from many channels of communication, e.g. the internet, informal networks or the specialist press, the mass media is arguably the most important of these channels (Mander and Gough, 2006).
}

tion goes out to the public (Nisbet and Scheufele, 2002; Scheufele and Lewenstein, 2005; Wynne, 1996), thus influencing the public debate by the way they interpret and present the information they receive from their sources (Hornig, 1993; Siegrist, 2000). Proponents of a technology are often anxious that the media will amplify the technology's possible risks, altering their message in a negative way (Bradbury and Dooley, 2004; Mander and Gough, 2006; Ryan, 1991). Vice versa, opponents of a technology may fear a 'hosanna atmosphere' created by the media. This implies that the understanding of complex technological issues by the lay public (whether or not that understanding is 'correct') relies heavily on the media, even if merely in terms of information diffusion (Ten Eyck, 2005). Therefore, we argue that media portrayals of CCS can provide heuristics for the understanding and assessment of the lay public's opinion on CCS technology.

The aim of this paper is to gain insight into the societal acceptance of CCS in the Netherlands, and to analyze whether and how this can influence further development and implementation of this technology. We have separated this extensive study into two parts. The main objective of the first part is to determine the stakeholders' attitudes and to pose conditions for the use of CCS technology in the Netherlands, as well as actions required to meet these conditions that have to be satisfied to increase stakeholder support for CCS. In the second part, we explore one of the determining factors in the public acceptance of CCS, i.e. the way the Dutch press perceives and portrays CCS.

The results of both parts are presented in this paper. In the following discussion, we will compare the stakeholders' attitudes with the portrayal of CCS by the media; in order to assess the extent to which the attributes of CCS are subject to a process of amplification by the way the media portray the technology. Subsequently, we will elaborate on the implications of these results for the deployment of CCS, which allows us to advice on how public policy on CCS can be improved.

\section{Design of stakeholder analysis}

The selection of stakeholders participating in this study was guided by the importance of their support for the implementation of CCS technology in the Netherlands, as well as their influence on the Dutch public opinion. The organizations that were chosen represent government, industry (associations), and environmental NGOs. With this selection, a balanced representation of the different stakeholder groups was pursued (see Table 1). Note that no research institutes participated in this study. The reason for this is that research institutes have been involved in earlier similar discussions and the minutes of those studies explicitly indicate that the discussion drifted to the technical side, so that acceptance as such was not adequately addressed (Dijk and Stollwerk, 2002).

Representatives of the selected organizations were interviewed and invited for a workshop. The purpose of 
Table 1

Stakeholder groups that participated in our study and their role in the development of CCS

\begin{tabular}{|c|c|c|}
\hline & Stakeholder & Role \\
\hline \multirow[t]{3}{*}{ Government } & $\begin{array}{l}\text { Ministry of Economic } \\
\text { Affairs }\end{array}$ & $\begin{array}{l}\text { This ministry is responsible } \\
\text { for energy policy and, thus, } \\
\text { for the national policy on } \\
\text { CCS }\end{array}$ \\
\hline & $\begin{array}{l}\text { Ministry of Housing, } \\
\text { Spatial planning and } \\
\text { Environment }\end{array}$ & $\begin{array}{l}\text { Climate change policy is one } \\
\text { of the main responsibilities } \\
\text { of this ministry }\end{array}$ \\
\hline & $\begin{array}{l}\text { Provincial governance } \\
\text { (Drenthe and } \\
\text { Limburg) }\end{array}$ & $\begin{array}{l}\text { These two provinces offer } \\
\text { possibilities for } \mathrm{CO}_{2} \text { storage } \\
\text { in depleted gas fields } \\
\text { (Drenthe) and coal beds } \\
\text { (Limburg) }\end{array}$ \\
\hline \multirow[t]{2}{*}{ Industry } & $\begin{array}{l}\text { Confederation of } \\
\text { Dutch Industry and } \\
\text { Employers } \\
\text { Federation of Energy } \\
\text { Companies } \\
\text { (EnergieNed) }\end{array}$ & $\begin{array}{l}\text { These umbrella } \\
\text { organizations represent the } \\
\text { interests of their member } \\
\text { companies, thus showing the } \\
\text { acceptance of CCS by } \\
\text { companies in general and by } \\
\text { energy companies in } \\
\text { particular }\end{array}$ \\
\hline & $\begin{array}{l}\text { Nederlandse Aardolie } \\
\text { Maatschappij BV and } \\
\text { Shell BV }\end{array}$ & $\begin{array}{l}\text { These companies are the } \\
\text { largest oil and gas producers } \\
\text { in the Netherlands and own } \\
\text { most of the (depleted) oil } \\
\text { and gas fields }\end{array}$ \\
\hline $\begin{array}{l}\text { Environment- } \\
\text { al NGOs }\end{array}$ & $\begin{array}{l}\text { World Wide Fund for } \\
\text { Nature, The Dutch } \\
\text { Society for Nature \& } \\
\text { Environment and } \\
\text { Greenpeace }\end{array}$ & $\begin{array}{l}\text { These environmental NGOs } \\
\text { are all engaged in the Dutch } \\
\text { CCS debate. In this debate, } \\
\text { Greenpeace operates } \\
\text { through confrontation and } \\
\text { action, while the other two } \\
\text { are proponents of } \\
\text { partnerships and open } \\
\text { dialogues with other } \\
\text { stakeholders }\end{array}$ \\
\hline
\end{tabular}

the in-depth interviews was to get a first impression of the attitudes of stakeholders towards CCS. Attitudes can be defined as evaluative and affective reactions to a particular subject, such as the deployment of CCS technology (Eagly and Chaiken, 1993). The output of the interviews and the results of comparable projects (PWC et al., 2001) were used to design a workshop around the questions whether CCS should be used to mitigate climate change and, if indeed this technology is to be used, what conditions would have to be satisfied to increase stakeholder support for CCS. With these two questions, insight is obtained into the acceptance of CCS by different stakeholder groups. To further deepen this insight, an additional step was made in the workshop in order to determine what actions and information are desired to meet the conditions for societal support of CCS.

The workshop took place in an Electronic Board Room (hardware) with a Group Decision Support System (software). This interactive, computer-based system facilitates participants to communicate simultaneously and anonymously on unstructured and semi-structured problems by brainstorming, giving comments, and voting on statements (Agterbosch et al., 2006). Generally speaking, a Group Decision Support System may positively affect the following aspects of problem analysis (Bongers, 2000; van de Herik, 1998):

- The system increases insight into the complexity of a problem: the involvement of different stakeholders can lead to a clustering of information and insights that, together, have a surplus value.

- It enables testing and evaluating: compared with individuals, a group of stakeholders can better assess the reality of results or solutions for a problem.

- It increases acceptance: involvement of a variety of interests may broaden the insight into the needs and points of view of different participants, which may contribute to the acceptance of solutions.

- It stimulates synergy and creativity: the involvement of different interests in the analysis of a problem can stimulate creativity when participants build on others' ideas, using insights and knowledge from different angles.

In our study, we used the characteristics of a Group Decision Support System to encourage open discussions between the stakeholders on different aspects of CCS; e.g. (long-term) risks and the role of CCS in the future energy supply system. These discussions elucidated the general attitude of several (groups of) stakeholders towards CCS. Furthermore, the system was used to discuss the conditions for increased stakeholder support in the process of realizing CCS in the Netherlands, and to vote on statements on the importance of these conditions. Finally, the stakeholders brainstormed on the actions required to meet these conditions for acceptance, and discussed the most promising ones. ${ }^{2}$

\section{Results of stakeholder analysis}

All parties consider climate change a serious and urgent problem lacking a simple solution. Government, industry, and environmental NGOs agree that CCS technology should be used to mitigate climate change. They argue that, in order to achieve substantial emission reductions, better energy efficiency, renewable energy, and CCS will all be needed simultaneously. Although most environmental NGOs see CCS technology as a necessary option to achieve the required carbon dioxide reductions, it is not their first choice. Their viewpoints range from 'not the favourite option' to an 'option of last resort'. According to the stakeholders participating in this study the role of CCS within this total package of climate measures should be

\footnotetext{
${ }^{2}$ For more practical details on the workshop see: van Voorst tot Voorst (2005).
} 
focused on achieving large amounts of carbon dioxide reductions in a relatively fast and easy way. CCS can be used to 'buy time' for the development and large-scale application of a more sustainable energy supply system.

Additionally, all parties emphasize that the climate problem calls for a global approach and they consider CCS as a global mitigation option with considerable potential. Particularly for countries such as China and India, where large coal reserves are being utilized to meet the rapidly increasing energy demands of their growing economies.

Despite the positive attitude towards CCS, the government, industry, and environmental NGOs pose several conditions on their support for the actual implementation of this technology, namely: safety, temporality \& partiality, financial stimuli, simplicity, cooperation \& commitment, and open communication. This set of conditions is detailed below. The description of each condition is followed by possible actions required to meet the condition. Only few references to particular stakeholder groups are made, because of a broad consensus among the stakeholders. In the cases where such specifications are absent, all stakeholders agreed on the condition and/or action offered.

\subsection{Safety}

A first condition for the acceptance of CCS is safety. CCS should be safe on the short term as well as on the long term, both for humans as well as for the environment in general. The understanding among all stakeholders is that the short-term (operational) risks can be adequately managed, because of industrial analogues such as acid gas injection, enhanced oil recovery, natural gas storage, and carbon dioxide pipeline transportation. Contrary to these short-term risks, the long-term risks are less well known. Leakage of carbon dioxide from the reservoirs is generally considered the largest risk. The consequences of carbon dioxide leakage are mainly of environmental nature, although the efficacy of CCS will also be reduced by leakage. The safety risks for human beings, on the other hand, are expected to be minimal.

The concerns about carbon dioxide leakage differ among the parties. In general, the industry trusts the technology and considers the risk of leakage small and well manageable. The government expects the risks to be small as well, but emphasizes that additional research is required. The environmental NGOs are most concerned about the leakage risks. Their concerns are mainly based on uncertainties, caused by a lack of knowledge of (the quantification of) possible leakage pathways, the behaviour of carbon dioxide in the underground, and the appropriate materials to seal abandoned injection wells.

These uncertainties regarding the CCS risks will have to be reduced in order to stimulate the acceptance of CCS by the various stakeholder groups, especially environmental NGOs. To accomplish this, the attendants of the workshop agreed that pilot projects will have to be initiated, taking into account the experiences of other (foreign) projects. Research on, for example, natural and industrial analogues will also be necessary. In order to optimally learn from demonstration projects, skilled monitoring will be necessary, which may require new monitoring techniques. To assure safety for longer periods of time, rules and standards will have to be developed for these monitoring techniques. This legislative framework should also contain requirements for storage site selection, operation and storage, and reporting (e.g. pressure, amounts of sequestered carbon dioxide). Finally, both government and environmental NGO representatives suggested creating a fund to be used for the compensation of unexpected consequences on the long term.

\subsection{Temporality \& partiality}

The second condition for the acceptance of CCS is that it should be used only temporarily and as a partial solution to the climate change problem. In this case, temporarily means for the duration of several decades. Since most stakeholders consider CCS an unsustainable 'end-of-pipe solution', it should not be used if more sustainable solutions become widely available, as can be expected on the longer term. At the same time though, the application term should not be shorter than 25 years, as various investments will have to be made and the industry is not willing to make those investment if the time period is too short to recover the costs.

Although most environmental NGOs consider CCS a necessary option to achieve the required carbon dioxide reductions, it is not their first choice. According to the NGOs, it should only be used as an addition to measures stimulating energy efficiency and the use of renewable energy. Furthermore, they emphasize that carbon dioxide emissions are not the only (unsustainable) problem of fossil fuels; there are for example the human casualties in coal mining and other harmful emissions than carbon dioxide. These problems will remain if CCS displaces learning and cost reductions in renewable energy technology.

The opinions differ as to whether action is required to assure the temporality of CCS. According to both government and industry, CCS will phase out over time due to market mechanisms. No specific action is required to assure temporality, as the potential of (cheap and safe) storage sites - which will be used first - is limited. Furthermore, new technologies will develop, making CCS superfluous or relatively too expensive in the long term. However, the environmental NGOs do not fully concur in this standpoint. CCS may phase out by itself, but whether this will indeed happen and, if so, when it will occur is not certain. For this reason, in the medium term, action might be required to assure the CCS' temporality. This action will have to be in the form of severe requirements for CCS (sites) e.g. more stringent licensing procedures and the stimulation of renewable energy technologies. 
To guarantee that efforts for CCS are not made at the expense of efforts for energy efficiency and renewable energy, the environmental NGOs propose a policy that links CCS support to increased funding for renewable energy and efficiency, e.g. by 'double matching': for each (government) Euro spent on CCS, at least two Euros should go to energy efficiency and sustainable energy. Other stakeholders did not share this requirement, because of the cost differences in measures to support energy efficiency and CCS technologies. However, they did not provide other clear actions that would satisfy the condition of partiality.

\subsection{Financial stimuli}

In order to make investments in CCS technologies attractive and acceptable for the industry, financial stimuli will be necessary. CCS is rather expensive, without yielding direct benefits for the investing company. Under the current circumstances, there are very few incentives for companies to invest in CCS: the capture and preparation of carbon dioxide reduces the energy efficiency of power plants. This 'energy penalty' also has its repercussions on the electricity price, which could lower the acceptance of CCS by the general public.

A first step towards financial stimuli for CCS is its inclusion in the European Union's Greenhouse Gas Emission Trading Scheme (EU ETS). By including CCS in the EU ETS, it will be part of a generic mechanism for carbon dioxide mitigation options. Specific measures for CCS are not desired, for they limit the freedom of companies and are less cost-effective. A second step is setting ambitious emission reduction targets for the postKyoto period. This will lead to lower emission ceilings for national industries, which will increase the price for carbon dioxide to a level that exceeds the costs of CCS and, thus, create a financial stimulus for its application. Furthermore, by setting targets, the financial uncertainty will be reduced resulting in a greater willingness of the industry to invest in carbon dioxide mitigation measures. According to the stakeholders attending the workshop, this will make CCS commercially attractive in due time after the first Kyoto period (2012). Ambitious emission reduction targets will also improve the acceptance of CCS by the environmental NGOs, as the chances that renewable energy and energy efficiency suffer from CCS efforts are reduced, since all of these options will be needed to achieve the targets.

\subsection{Simplicity}

A fourth condition is that CCS should not be made more complex than necessary. This means it should not be linked obligatorily to other possible advantages, such as hydrogen or coal bed methane production. The rationale is that CCS is complex enough in itself. Despite this complexity, it can be implemented relatively soon and in a relatively easy and cheap way. However, these advantages could disperse if
CCS is combined obligatorily with other, possibly more complex, purposes. Additionally, the climate change might have such far-reaching effects, that no additional reason is needed to justify the deployment of CCS. A government representative added that obligatory links could also incur risks: if the anticipated additional advantages turn out to be disappointing, the public support for CCS might decline.

The participants of the workshop considered the origin of the carbon dioxide for sequestration irrelevant: the purpose of CCS is to keep carbon dioxide out of the atmosphere and not to facilitate a hydrogen economy. The way the carbon dioxide is captured is not relevant for this purpose, nor for the acceptance of this technology. The process is only relevant for the costs of carbon dioxide.

No action is required to fulfil this condition. The combination of CCS with hydrogen production or other additional advantages should not be made obligatory. If this combination occurs, it should be in the hands of the market instead of the legislator.

\subsection{Cooperation \& Commitment}

A fifth condition for acceptance is commitment of and cooperation between different sectors. The Netherlands has competitive advantages in the field of CCS because of the presence of (nearly) depleted natural gas reservoirs as well as other storage options and the considerable knowledge of CCS within a number of companies and research institutes. In order to take advantage of this strategic position, cooperation between and commitment of various parties as well as a long-term vision will be necessary. Both industry and government raised this point. Coordination can bring existing knowledge and expertise together, and promote the best options to be identified and used. Additionally, a proper coordination of activities will stimulate learning and prevent double work and unnecessary investments. Representatives of both industry and government gave the example that cooperation between parties may prevent production wells of depleted gas fields from being sealed, so that no new wells will have to be drilled when the decision is made to inject carbon dioxide into those fields.

The action required for the fulfilment of this condition is to collectively draw up a plan for the implementation and application of CCS. This plan will have to be based on the strategic positions of the parties involved as well as their responsibilities. Furthermore, it should present what needs to be done at what moment. In other words, a roadmap for the implementation of CCS should be drawn up. This will reduce the uncertainties regarding investment decisions for CCS and improve the commitment and, thus, the reliability of the different parties involved. Additionally, as an industry representative noted, if the parties are able to cooperate and coordinate efficiently, there will be substantial business opportunities for this option to export the gained knowledge and experience. 


\subsection{Open communication}

The sixth condition is open communication about CCS to the public. To create and maintain public acceptance, appropriate communication is essential. Without public acceptance, the stakeholder groups - particularly the industry - will not contribute to the implementation and use of CCS, for they will consider it too risky. If CCS is to be implemented on a larger scale, communication to the public will have to be intensified and organized in such a way that it creates public awareness and understanding. Therefore, the conditions mentioned above will have to be met and communicated properly to the public at large. However, the stakeholders did note that the conditions that have to be satisfied to increase their support for CCS might be quite different from the concrete acceptance of storage at a specific site by local communities.

This 'not in my backyard principle' (NIMBY) can be reduced by giving local communities the opportunity to voice their concerns, and by providing additional benefits. In order to create societal acceptance at large, open, clear, two-way and well-timed communication of information will be necessary, putting CCS in the broader perspective of climate change. According to all stakeholders, the public will should become aware of the fact that climate change is a serious and urgent problem, and that CCS is needed to solve this problem. Furthermore, the risks of climate change will need to be communicated in a clear and-for the public - understandable language. The 'CCS message' should be based on experience, knowledge, and facts as much as possible, and refer to current projects and analogues. Communication to society is a joint responsibility of all organizations involved and includes consultation of the public.

\section{Design of media analysis}

The stakeholder analyses showed that government, industry, and environmental NGOs do not expect the acceptance of CCS technology by the general public to be a major problem, provided that the conditions discussed in the previous section are met and communicated to society in an open and understandable way. Besides consultation, this communication should include the stakeholders' consensus view, that climate change is a serious global problem, that rigorous emission reductions are needed to reduce this threat, and that CCS is an effective means to accomplish this. However, the established mass communication media, such as newspapers, influence this communication to the public by the way they interpret and 'frame' information on CCS (Mander and Gough, 2006).

This part of our study focuses on the role of the print media in framing CCS technology in their communication to the public. Therefore, all documents related to CCS in the main Dutch daily newspapers were retrieved from the LexisNexis ${ }^{\circledR}$ Academic database. The terminology for
CCS used in the press releases of the Intergovernmental Panel for Climate Change (IPCC) was taken as a starting point. These terms were translated for the Dutch language and used in the database to obtain a sample of 30 newspaper articles. These articles were analyzed to find various translations of 'carbon capture and storage'. Search terminology comprised: 'Schoon Fossiel' OR 'CO2' OR 'kooldioxide' OR 'Koolstofdioxide' AND 'opslag' OR 'afvang' OR 'sequestratie'; these terms were used to obtain the final set of articles to be used for this report. This set contained several irrelevant articles, for example describing carbon storage in forests. These articles were removed and the remaining set comprised 306 articles, covering a time period from 1991 — when the first article appeared - until June 2006.

In the content analysis of the Dutch news articles on CCS, first of all, we focused on the events that triggered the publication of these articles, such as policy announcements, or the release of scientific reports. We explored the extent to which external events stimulate media coverage and influence the way the press perceives and portrays CCS. For example, an increase in these 'trigger events' could change the way the media interpret and, subsequently, presents CCS to the public. Furthermore, it gives an indication of the recognition of CCS in the media (as more CCS related issues are being published) and it presents the background for the media portrayals of CCS technology. This helps to understand the articulation of key issues related to CCS in the Dutch media.

This articulation process is depicted by the distribution of positive, negative, and neutral articles over time. Articles were classified 'positive' if the majority of statements used in the article were in favour of CCS, 'neutral' if the number of negative and positive statements was balanced, and 'negative' if the majority of statements and the overall impression of the article were negative towards CCS. A fourth category was introduced, indicating whether CCS is mentioned in an article but not discussed as such. A second researcher checked this classification, after which differences were discussed to harmonize the classification procedure. In cases of doubt, more attention was paid to the title and the first few lines of the article.

Finally, the main arguments in favour or against CCS were distilled from each article, as well as the type of actors linked to these arguments if they were cited in the article. This enables a comparison between the statements that stakeholders made during the workshop and the ones depicted by the media. This will be done in the discussion of this paper, wherein the results of the stakeholder analysis and this study on the portrayal of CCS by the print media will be discussed and compared.

\section{Results of media analysis}

CCS received considerably more attention by the media from 2005 onwards. Partly, the increasing number of 
articles discussing CCS is a consequence of the fact that there were an increasing number of events to report. Fig. 1 relates the annual distribution of CCS articles to 'trigger events' such as the release of scientific reports, and the launch of specific commercial projects. It shows that the increasing number of CCS projects, together with a more intense climate change debate in recent years, not only have led to increased media attention for CCS, but also to a more positive portrayal of CCS in the press.

\section{1. $1991-1996$}

Fig. 1 shows that in the early nineties, CCS did not get much press attention. The possibility to store carbon dioxide underground was first reported in relation to a demonstration coal gasification plant in Buggenum. A year later, CCS was mentioned in relation to the Earth Summit in Rio de Janeiro, the Dutch Energy Outlook 1990-2015 (Boonekamp et al., 1992) and the First International Conference on Carbon Dioxide Removal held in Amsterdam (Turkenburg et al., 1992). This did not lead to any pilot projects, because of the disapproval of such projects by the Dutch Energy Council (AER, 1994) and a reserved stance of the ministry of economic affairs. Even though the style of discourse used in relation to CCS was rather cautious in the mid-nineties, media attention started to grow with the publication of the IPCC (1995) Special Report on Climate Change and subsequent Dutch reports on this matter by the Centre for Energy Conservation (CE, 1996) and the Dutch Organization for Applied Scientific Research (TNO/RGD, 1996).

\section{2. $1997-2000$}

Following the example of Statoil-the company that started the storage of carbon dioxide in the Norwegian North Sea-Shell announced their plans to store the carbon dioxide stream from the Shell Pernis refinery. This announcement triggered fair media attention in 1997, especially after the Conference of Parties (CoP) III in Kyoto. Eventually, the carbon dioxide from Shell Pernis was not stored underground, but transported to greenhouse horticulture in order to meet the carbon dioxide requirement. This plan was approved in 1999 and realized by OCAP (2004). In that same year, media attention for CCS was related to the Dutch debate on the limited allowance of natural gas drilling in the 'Waddenzee'. (The storage of carbon dioxide is an option to prevent subsidence of depleted gas fields.) Furthermore, a policy document on climate change by the Ministry of Housing, Spatial planning, and Environment (VROM, 1999), referred to CCS as the most important back-up option for the Netherlands to reach its emission reduction targets as formulated in the Kyoto protocol. At the end of the millennium, the way CCS was covered by the press shifted slightly from 'neutral' to 'positive'.

\section{3. $2001-2004$}

This trend continued with the press coverage of the CoP6 in The Hague, which was an important stimulus for the realization of the $\mathrm{CO}_{2}$ Re-use through Underground Storage (CRUST) project (Dijk and Stollwerk, 2002). This

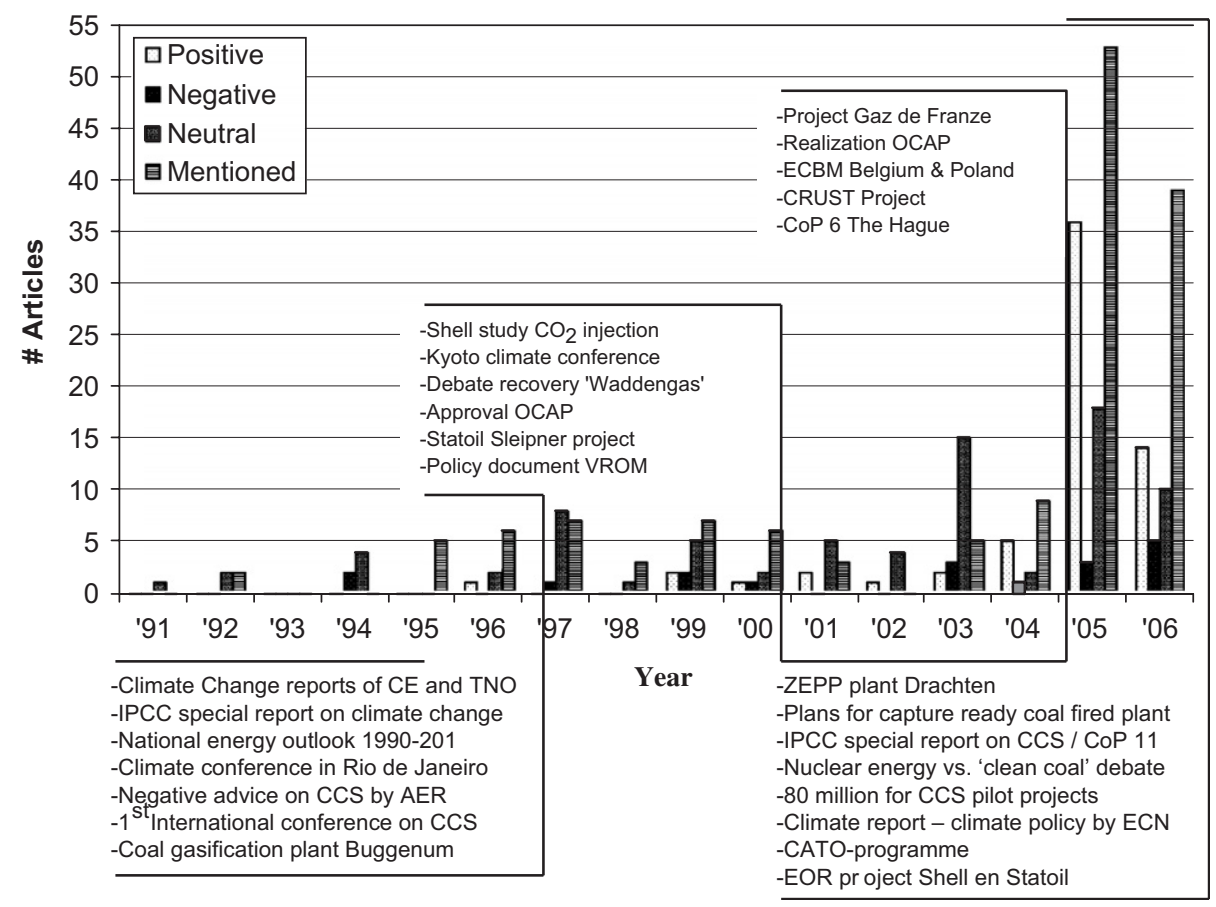

Fig. 1. The number of articles on CCS published in Dutch newspapers in the period 1991-2006; subdivided in positive, negative, neutral and 'only mentioned' articles and related to key 'trigger events'. 
project was covered quite extensively in the media in 2002. In 2003 and 2004, the news articles on CCS were dominated by several CCS projects in both the Netherlands and abroad. The project receiving most media coverage (mostly positively) was the domestic carbon dioxide storage experiment in the North Sea (field K12-B), carried out by Gaz de France and monitored by the Dutch Organization for Applied Scientific Research (TNONITG). Furthermore, there was some media attention for the RECOPOL project in Poland, where carbon dioxide is used for enhanced coal bed methane production (ECBM), and for the research performed by the Flemish Institute for Technological Research on the possibility to store carbon dioxide in the Flemish coalmines.

\subsection{5-June 2006}

As shown in Fig. 1, the amount of news articles on CCS in 2005 and the first half of 2006 is quite high compared to the previous years. Nearly two-thirds of all the press articles were released in the last 1.5 years. This can be explained by the increasing number of CCS related events in this period, and by the fact that the projects and plans for CCS implementation have become more concrete. In the beginning of 2005, three possible locations for zero emission power plants (ZPPs) are discussed in the media. Most of the attention is focused on SEQ B.V., planning to build a ZPP in cooperation with the 'Nederlandse Aardolie Maatschappij' in the north of the Netherlands (city of Drachten). Apart from this project, CCS is mentioned in several articles related to the realization of new coal plants in the 'Maasvlakte' (city of Rotterdam) and the 'Sloegebied' (province of Zeeland). The newspapers report on the possibility to equip these new power plants with capture technology, as an alternative to expand the nuclear energy capacity as a greenhouse gas mitigation strategy. This discussion on the possible role of CCS in the future energy supply system of the Netherlands was partly initiated by the realization of national research program on CCS (CATO). Other primary trigger events for this debate was the release of the IPCC Special Report on CCS (2005), the CoP 11 in Montreal, and the first National Conference on CCS in the Netherlands; both held in 2005 .

The debate on nuclear versus 'clean coal' was extensively covered by the media and one of its outcomes in 2006 was that the current nuclear plant (Borsele) in the Netherlands will be kept open for a longer period of time, i.e. until 2030, instead of 2010, and that part of the revenues (80 million Euros) are reserved for CCS demonstration projects. This corresponded with an influential report presented by the Energy Research Centre of the Netherlands (ECN) and the Dutch Environmental Planning Bureau (2006), proclaiming nuclear energy and CCS to be the most affordable options when it comes to achieving the emission reduction targets on the short term. Some more recent news articles on CCS cover the agreement between Shell and Statoil to work towards developing the world's largest project using carbon dioxide for enhanced oil recovery offshore.

What is striking in the augmenting media attention for CCS is not only the considerable increase in the absolute number of news articles, but also the rising amount of 'positive' articles (see Table 2). If we leave out the articles in which CCS is only being mentioned briefly and the ones in which it is referred to as an item in the discussion of another topic, the relative share of positive articles has risen from approximately $10 \%$ in the nineties to almost $60 \%$ in the last 1.5 years. On average, the share of negative articles per year has decreased from $17 \%$ in the first two time periods to $10 \%$ from 2000 onwards. The percentage of neutral articles has dropped from an average of $70 \%$ between 1991 and 2004 to $31 \%$ in the last 1.5 years. This trend corresponds with the increase in favourable statements on CCS in the Dutch media, which are presented in Table 3.

Table 3 clearly shows that one of the major themes in the news articles, namely the 'promise' that CCS could help accomplish a significant reduction in carbon dioxide emissions into the atmosphere, has been dominant throughout the whole time period. Various attributes of this promise relate to the large geological potential for CCS, the existing expertise on this technology, and the realization of successful pilot projects. Furthermore, economic arguments contribute to the positive portrayal of CCS in the Dutch media, i.e. its cost-effectiveness compared to other carbon dioxide mitigation options, the possibility for enhanced oil and gas recovery, and business opportunities for Dutch companies.

The issues of concern as raised by the Dutch print media are summarized in Table 4. Even though CCS is considered to be cost-effective compared with other carbon dioxide mitigation strategies, there are high costs involved in the deployment of CCS. At this moment CCS substantially reduces the energy efficiency of coal or gas fired plants. Therefore, large RD\&D investments are needed to lower this energy penalty and, thus, a substantial part of the costs involved in CCS. This issue is raised most frequently in articles expressing concern about CCS technology. Interestingly enough, and in contrast to the positive statement of CCS being part of a broad carbon mitigation portfolio, several articles proclaimed that funding CCS might come at the expense of the support of other mitigation technologies. Given the fact that, in some articles, CCS is considered an end-of-pipe solution, government money

Table 2

Overall portrayal of CCS in Dutch print media in four different time periods

\begin{tabular}{llll}
\hline Year & Positive (\%) & Negative (\%) & Neutral (\%) \\
\hline $1991-1996$ & 8 & 17 & 75 \\
$1997-2000$ & 13 & 17 & 70 \\
2001-2004 & 25 & 10 & 65 \\
2005-June 2006 & 59 & 10 & 31 \\
\hline
\end{tabular}


Table 3

Number and share of positive statements in Dutch news articles on CCS

\begin{tabular}{|c|c|c|c|c|c|c|}
\hline \multirow{2}{*}{$\begin{array}{l}\text { Year } \\
\text { Positive statements }\end{array}$} & \multicolumn{2}{|c|}{ 2005-June 2006} & \multicolumn{2}{|c|}{ 1991-2004 } & \multicolumn{2}{|c|}{ Total } \\
\hline & nr. & $\%$ & nr. & $\%$ & nr. & $\%$ \\
\hline 1. $\mathrm{CO}_{2}$ emission reduction (while using fossil fuels) & 54 & 32 & 45 & 32 & 99 & 32 \\
\hline 2. Large mitigation potential & 18 & 11 & 16 & 11 & 34 & 11 \\
\hline 3. Cost-effectiveness (compared to renewable energy technologies) & 11 & 7 & 13 & 9 & 24 & 8 \\
\hline 4. Successful (foreign) pilot projects & 11 & 7 & 13 & 9 & 22 & 7 \\
\hline 5. Part of broad energy supply portfolio against climate change & 13 & 8 & 5 & 4 & 18 & 6 \\
\hline 6. Enhanced oil/gas recovery & 9 & 5 & 8 & 6 & 17 & 6 \\
\hline 7. Well-known technologies (reliable technology available) & 9 & 5 & 8 & 6 & 17 & 6 \\
\hline 8. Business opportunities for Dutch companies & 11 & 7 & 3 & 2 & 14 & 5 \\
\hline 9. Well sealed reservoirs available & 9 & 5 & 6 & 4 & 15 & 5 \\
\hline 10. Help against subsidence & 4 & 2 & 6 & 4 & 10 & 3 \\
\hline 11. Short-term option & 3 & 2 & 7 & 5 & 10 & 3 \\
\hline 12. Alternative for nuclear & 7 & 4 & 2 & 1 & 9 & 3 \\
\hline 13. Bridge to hydrogen economy (options for transport sector) & 2 & 1 & 6 & 4 & 8 & 3 \\
\hline 14. Less dependent on fossil fuel imports (security of supply) & 4 & 2 & 0 & 0 & 4 & 1 \\
\hline 15. Compatible with current energy system & 1 & 1 & 1 & 1 & 2 & 1 \\
\hline 16. Answer to growing global fossil fuel demand (India, China) & 1 & 1 & 1 & 1 & 2 & 1 \\
\hline Average (number of arguments per article) & \multicolumn{2}{|c|}{2.6} & \multicolumn{2}{|c|}{1.8} & \multicolumn{2}{|c|}{2.1} \\
\hline
\end{tabular}

Table 4

Number and share of negative statements in Dutch news articles on CCS

\begin{tabular}{|c|c|c|c|c|c|c|}
\hline \multirow{2}{*}{$\begin{array}{l}\text { Year } \\
\text { Negative statements }\end{array}$} & \multicolumn{2}{|c|}{ 2005-June 2006} & \multicolumn{2}{|c|}{ 1991-2004 } & \multicolumn{2}{|c|}{ Total } \\
\hline & nr. & $\%$ & nr. & $\%$ & nr. & $\%$ \\
\hline 1. High costs & 14 & 17 & 20 & 25 & 34 & 21 \\
\hline 2. End-of-pipe solution (no solution to the problem) & 8 & 10 & 14 & 17 & 22 & 13 \\
\hline 3. Risks (general) & 7 & 8 & 8 & 10 & 15 & 9 \\
\hline 4. Threat for renewable energy/energy efficiency & 10 & 12 & 4 & 5 & 14 & 8 \\
\hline 5. Technology not ready (proven) & 7 & 8 & 6 & 7 & 13 & 8 \\
\hline 6. Government support needed (dependent on subsidies) & 11 & 13 & 2 & 2 & 13 & 8 \\
\hline 7. Energy penalty & 5 & 6 & 5 & 6 & 10 & 6 \\
\hline 8. Ecological risks through leakage & 6 & 7 & 3 & 4 & 9 & 5 \\
\hline 9. Continuing fossil fuel dependency & 2 & 2 & 3 & 4 & 5 & 3 \\
\hline 10. Uncertain public acceptance & 1 & 1 & 4 & 5 & 5 & 3 \\
\hline 11. Stimulation of fossil fuel use (indirect support for 'dirty' coal) & 4 & 5 & 0 & 0 & 4 & 2 \\
\hline 12. Uncertainty about reservoir behaviour & 2 & 2 & 2 & 2 & 4 & 2 \\
\hline 13. Responsibility issues & 2 & 2 & 2 & 2 & 4 & 2 \\
\hline 14. Lock-in (sub-optimal) of technology (not renewable) & 2 & 2 & 1 & 1 & 3 & 2 \\
\hline 15. Against principle 'polluter pays' & 2 & 2 & 1 & 1 & 3 & 2 \\
\hline 16. Human health risks & 1 & 1 & 2 & 2 & 3 & 2 \\
\hline 17. Spatial planning problems (well drilling) & 1 & 1 & 1 & 1 & 2 & 1 \\
\hline 18. Seismic effects & 0 & 0 & 2 & 2 & 2 & 1 \\
\hline 19. Limited potential & 0 & 0 & 1 & 1 & 1 & 1 \\
\hline Average (number of arguments per article) & \multicolumn{2}{|c|}{1.2} & \multicolumn{2}{|c|}{0.9} & \multicolumn{2}{|c|}{1.0} \\
\hline
\end{tabular}

should not be spent on this option. Another frequent concern ventilated in news articles-both in general and specified-are the risks of using CCS.

Tables 3 and 4 show that apart from the increasing number of events reported by the media in the last time period, there are more arguments used per article in the portrayal of CCS, both of which indicate that the discussion on CCS is becoming a regular and grounded part of the discourse. The increase in negative statements in
2006 compared with 2005, might be explained by a relatively strong media campaign by environmental NGOs (in this case Greenpeace) against the plans of the national government to stimulate the use of CCS with public money. This is depicted in Fig. 2, which shows that the environmental NGOs in particular express their concerns about the development of CCS technology. It also clearly shows that the Dutch research bodies are neutral to slightly positive when referred to in the newspapers. The govern- 


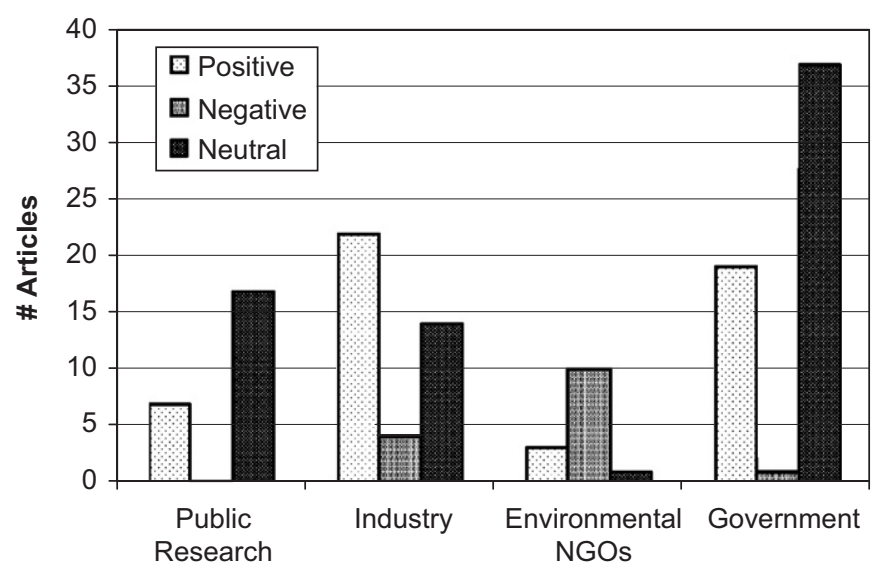

Fig. 2. Attitudes of main stakeholders towards CCS; expressed (cited) in the Dutch print media between 2005 and June 2006.

ment, having been rather neutral on CCS for many years, recently started shifting towards a more positive attitude, seemingly influenced by the opinion of the industry, where the benefits of CCS have been proclaimed for a longer period of time.

\section{Conclusions and discussion}

The stakeholder analysis shows that, as far as the government, industry, and environmental NGOs, are concerned, there is a positive attitude towards CCS technologies in the Netherlands. Although most environmental NGOs see CCS technology as a effective option to achieve the required carbon dioxide reductions, it is not their first choice. Their acceptance of CCS can be characterized as 'reluctant' rather than 'enthusiastic'. Despite the fundamentally positive attitude towards CCS, stakeholders pose several conditions for their support of the actual implementation of CCS. A broad consensus exists as to what these conditions should be. The first condition is that CCS should be safe, on the short term as well as on the long term, and for human beings as well as for the environment. The second condition is that CCS should be deployed temporarily and partially. It should only be used for a few decades and efforts for CCS should not be made at the expense of more sustainable options. The third condition is simplicity, meaning it should not be made more complex than necessary by obliging a link with other purposes. Fourth, financial stimuli are necessary in order to make investments in CCS acceptable for the industry. Furthermore, commitment of and cooperation between different stakeholders is considered a crucial condition for the successful implementation of CCS. The sixth condition is an open communication on CCS to the public; this communication should be based on experience, knowledge, and facts as much as possible. The latter is a responsibility of both stakeholders and media, as the way in which the media portray this new technology can radically affect the success of its implementation.
The results of our analysis on the portrayal of CCS in the Dutch media show that, up till now, the information on CCS is neither dramatized, nor hyped by the media. Instead, the technology is presented in a balanced to positive way, with great emphasis on the benefits of allowing continued fossil fuel use, while addressing climate change concerns. This positive representation of CCS has become more dominant in recent years, when most of the news articles on CCS were published. The increased number of (international) events concerning CCS - e.g. pilot projects and a more thorough climate change debate - have caused this growth in media attention for CCS. The same trend has been found in other countries. This was shown by Gough and Mander (2006), who studied the impact of the publication of the IPCC Special Report on CCS on the portrayal of CCS in the print media of five English speaking countries: the United Kingdom, the United States, Australia, Canada, and New Zealand. Similar results were found for Germany, France, Italy, and Spain by the Institute for Innovation and Learning (I2L, 2006). In all of the countries surveyed in these studies, more articles about CCS technology were neutral to positive than negative.

Despite the fact that the concerns about CCS have not overshadowed the main promise that CCS is part of the solution to climate change, the media did pay attention to the possible weaknesses of this technology. These negative statements expressed in the print media were quite similar to the concerns raised by the stakeholders participating in this research, as depicted in Table 5. This similarity between stakeholders' attitudes and media portrayals of CCS provides some evidence that the way the media present CCS is - to a certain extent-a balanced reflection of the way the stakeholders perceive CCS.

The current negative aspects of CCS as raised by different stakeholders and the media will remain if no action is taken. It is reasonable to assume that the stakeholders who raised these concerns-NGOs in particular - will find the media again to express them. Earlier research by Shackley et al. (2004) showed that levels of trust in key institutions, like NGOs, and the information given by the media have a major influence on how CCS will be perceived by the general public. Therefore, the conditions posed on the use of CCS, as well as the actions required to meet these conditions (see Table 5) articulate important issues concerning the future societal acceptance of CCS in the Netherlands. These insights in the potential societal responses is useful to overcome possible impediments created by various societal groups and effectively design public policy for this technology. The (policy) strategies proposed by the stakeholders to deal with their most critical concerns and those of expressed by the media are discussed below.

The uncertainties regarding the safety and environmental risks involved in CCS will have to be reduced in order to stimulate acceptance. To achieve this, first of all, pilot projects for underground storage will have to be initiated 
Table 5

Overview of concerns towards CCS raised by media; conditions posed by stakeholders on the deployment of CCS, and the actions required to meet them

\begin{tabular}{|c|c|c|}
\hline $\begin{array}{l}\text { Concerns } \\
\text { raised by media }\end{array}$ & Conditions & $\begin{array}{l}\text { Actions proposed by } \\
\text { stakeholders }\end{array}$ \\
\hline $\begin{array}{l}\text { Ecological and } \\
\text { human health } \\
\text { risks through } \\
\text { leakage; and } \\
\text { uncertainty } \\
\text { about reservoir } \\
\text { behaviour/ }\end{array}$ & Safety & $\begin{array}{l}\text { Initiation of (pilot) } \\
\text { projects, more scientific } \\
\text { research; and } \\
\text { development of rules and } \\
\text { standards for storage site } \\
\text { selection, storage and } \\
\text { monitoring }\end{array}$ \\
\hline
\end{tabular}

seismic effects

\begin{tabular}{|c|c|c|}
\hline $\begin{array}{l}\text { Threat for } \\
\text { renewable } \\
\text { energy; } \\
\text { continuing } \\
\text { fossil fuel } \\
\text { dependency } \\
\text { (lockin } \\
\text { suboptimal } \\
\text { technology); } \\
\text { and 'end of } \\
\text { pipe' solution }\end{array}$ & $\begin{array}{l}\text { Temporality and } \\
\text { partiality }\end{array}$ & $\begin{array}{l}\text { Develop a legislative } \\
\text { framework on reservoir } \\
\text { requirements; and make } \\
\text { support for CCS } \\
\text { contingent on increased } \\
\text { funding for renewable } \\
\text { energy; e.g. by 'double } \\
\text { matching' }\end{array}$ \\
\hline $\begin{array}{l}\text { High costs of } \\
\text { technology } \\
\text { (energy } \\
\text { penalty) and } \\
\text { the need for } \\
\text { government } \\
\text { support }\end{array}$ & Financial stimuli & $\begin{array}{l}\text { Stimulate extra R\&D } \\
\text { efforts. Use generic } \\
\text { mechanisms; e.g. the } \\
\text { inclusion in EU ETS, } \\
\text { complemented by } \\
\text { ambitious post Kyoto } \\
\text { targets }\end{array}$ \\
\hline $\begin{array}{l}\text { Technology not } \\
\text { proven and } \\
\text { limited } \\
\text { potential }\end{array}$ & Simplicity & $\begin{array}{l}\text { Prevention of obligatory } \\
\text { links and 'Goldplate' } \\
\text { first projects }\end{array}$ \\
\hline $\begin{array}{l}\text { Responsibility } \\
\text { issues and } \\
\text { spatial } \\
\text { planning } \\
\text { problems }\end{array}$ & $\begin{array}{l}\text { Cooperation and } \\
\text { commitment }\end{array}$ & $\begin{array}{l}\text { Drawing up a roadmap } \\
\text { and create public private } \\
\text { partnerships }\end{array}$ \\
\hline $\begin{array}{l}\text { Risk of } \\
\text { NIMBYism } \\
\text { and uncertain } \\
\text { public } \\
\text { acceptance }\end{array}$ & Open communication & $\begin{array}{l}\text { Establish an open, two- } \\
\text { way communication and } \\
\text { present CCS in a broader } \\
\text { context of climate } \\
\text { change, as part of broad } \\
\text { portfolio of options }\end{array}$ \\
\hline
\end{tabular}

and complemented with scientific research. Second, rules and standards will have to be developed for new monitoring techniques, to assure safety for longer periods of time. This legislative framework should also contain requirements for storage site selection, operation and storage. Such a stringent storage framework could help actuate the phase-out of CCS on the longer term and stimulate more sustainable technological options. To guarantee that CCS efforts are not made at the expense of energy efficiency and renewable energy, the environmental NGOs propose a policy that makes support for CCS contingent on increased funding for renewable energy and energy efficiency.
There is an urgent need for a legislative framework that provides the necessary financial stimuli to allow investments in CCS technology. This could be achieved by the inclusion of CCS in the EU ETS, thus making it part of a generic mechanism for carbon dioxide mitigation options. However, in order to establish a carbon price that makes CCS investments worthwhile, ambitious emission reduction targets for the post-Kyoto period will need to be set.

In order to make CCS investments attractive for Industry, CCS should not be linked obligatory with other possible advantages. Adding obligatory links might incur risks: if the anticipated additional advantages turn out to be disappointing, the public acceptance of CCS might decline. Especially in the early development phases of CCS, a single failure may lead to societal opposition. To facilitate the implementation of CCS projects, partnerships between the government, environmental NGOs, public research institutes, and the energy industry need to be established. Such partnerships should include a collective plan for the implementation and application of CCS. In other words, a roadmap for the use of CCS should be drawn up.

The communication of such an implementation plan to society is a joint responsibility of all stakeholders involved. A distinction should be made between communications to the general public and to citizens burdened by a single CCS project. The acceptance of the latter could be achieved by giving these local communities the opportunity to voice their concerns and by providing additional benefits. To create societal acceptance at large, open, clear, twoway and well-timed communication is needed, clearly putting CCS in the broader context of climate change and the range of possible solutions for a more sustainable future. A greater understanding of the urgency and severity of the climate change problem will make CCS more acceptable.

\section{Acknowledgements}

We would like to gratefully acknowledge Gerd Jan Kramer (Shell Global Solutions), for his cooperation with and supervision of Quirine van Voorst tot Voorst during her internship at Shell Global Solutions International BV, and Jan Paul van Soest (Former Chairman of the CRUSTproject) for his advice during the preparation of the stakeholders workshop. We would also like to thank Wim Turkenburg (Utrecht University) and Dancker Daamen (Leiden University) for their inspiring and helpful comments on earlier versions of this paper, as well as the anonymous reviewers of this journal who put in a lot of effort to improve the quality of this paper. Finally we are grateful to Marjan Ossebaard (I2L) for her valuable contribution to the media analysis. This research is part of the CATO program, the Dutch national research program on Carbon dioxide Capture and Storage. The Dutch Ministry of Economic Affairs (EZ) and the consortium partners financially support CATO. 


\section{References}

AER, 1994. Advies AER over de Vervolgnota Energiebesparing. Den Haag, Algemene Energieraad.

Agterbosch, S., Glasbergen, P., Vermeulen, W.J.V., 2006. Social barriers in wind power implementation in The Netherlands: perceptions of wind power entrepreneurs and local civil servants of institutional and social conditions in realizing wind power projects. Renewable \& Sustainable Energy Reviews, in press, Corrected Proof.

Ashworth, P., Littleboy, A., Pisarski, A., Beath, A., Thambimuthu, K., 2006. Understanding and incorporating stakeholder perspectives to low emission technologies in Australia. Eighth International Conference on Greenhouse Gas Control Technologies (GHGT-8), Trondheim, Norway.

Bongers, F.J., 2000. Participatory Policy Analysis and Group Support Systems. Tilburg, Katholieke Universiteit Braband.

Boonekamp, P.G.M., van Hilten, O., Kroon, R., Rouw, M.N.E.V., 1992. Nationale Energie Verkenningen 1990-2015. ECH Report no. ECN-C-92-017, Petten, Netherlands Energy Research Foundation (ECN).

Bradbury, J., Dooley, J., 2004. Who's talking? What are the issues? The media portrayal of carbon dioxide capture and sequestration in the United States. Seventh International Conference on Greenhouse Gas Control Technologies (GHGT-7), Vancouver, Canada.

CE, 1996. Nationale themadag waterstof. Delft (Netherlands), Centre for Energy Conservation and Environmental Technology.

Curry, T., Reiner, D.M., Ansolabehere, S., Herzog, H.J., 2004. How aware is the public of carbon capture and storage? Seventh International Conference on Greenhouse Gas Control Technologies (GHGT-7), Vancouver, Canada.

Daamen, D., de Best-Waldhober, M., Damen, K., Faaij, A., 2006. Pseudo-opinions on CCS technologies. Eighth International Conference on Greenhouse Gas Control Technologies (GHGT-8), Trondheim, Norway.

de Best-Waldhober, M., Daamen, D., 2006. Public Perceptions and Preferences Regarding Large Scale Implementation of Six $\mathrm{CO}_{2}$ Capture and Storage Technologies. Centre for Energy and Environmental Studies, Leiden University, Leiden.

de Best-Waldhober, M., Daamen, D., Faaij, A., 2006. Informed public opinions on $\mathrm{CO}_{2}$-capture and storage technologies. Eighth International Conference on Greenhouse Gas Control Technologies (GHGT8), Trondheim, Norway.

de Coninck, H., Anderson, J., Curnow, P., Flach, T., Flagstad, O., Groenenberg, H., Norton, C., Reiner, D., Shackley, S., 2006. Acceptability of $\mathrm{CO}_{2}$ capture and storage - a review of legal, regulatory, economic and social aspects of $\mathrm{CO}_{2}$ capture and storage, Energy Research Centre of the Netherlands.

Devine-Wright, P., 2005. Beyond NIMBYism: towards an integrated framework for understanding public perceptions of wind energy. Wind Energy 22 (2), 125-139.

Devlin, E., 2005. Factors affecting public acceptance of wind turbines in Sweden. Wind Engineering 29 (6), 503-511.

Dietrich, H., Schibeci, R., 2004. Beyond public perceptions of gene technology: community participation in public policy in Australia. Public Understanding of Science 12, 381-401.

Dijk, J.W., Stollwerk, P.J., 2002. $\mathrm{CO}_{2}$ reuse through underground storage - the start-up: an inventory of market opportunities, technology and policy requirements. $\mathrm{CO}_{2}$ Reduction Plan Project Office, Zwolle.

Eagly, A.H., Chaiken, S., 1993. The Psychology of Attitudes. Harcourt Brace Jovanovich College Publishers, Forth Worth.

ECN and NMP, 2006. In: Daniels, B.W., Farla, J.W.M. (Eds.), Optiedocument Energie en Emissies 2010/2020. Petten/Bilthoven, Energy Research Centre of the Netherlands and Dutch Environmental Planning Bureau.

EEA, 2004. Impacts of Europe's changing climate, an indicatorbased assessment. European Environmental Agency, Copenhagen, Denmark.
Gough, C., Mander, S., 2006. Carbon Dioxide Capture and Storage in the Media. I. G. G. Programme, Tyndall Centre for Climate Change Research.

Gough, C., Shackley, S., 2006. Towards a multi-criteria methodology for assessment of geological carbon storage options. Climate Change 74 (1-3), 141-174.

Hornig, S., 1993. Reading risk: public response to print media accounts of technological risk. Public Understanding of Science 2, 95-109.

Huijts, 2003. Public perception of Carbon Dioxide Storage. Eindhoven University of Technology, Eindhoven.

I2L, 2006. The impact of the 'IPCC Special Report on Caron Capture and Storage' on written news reports, I2L-Institute for Innovation and Learning, Utrecht.

IPCC, 1995. Climate Change 1995: impacts, adaptations and mitigation of climate change: scientific-technical analyses. In: Watson, R.T., Zinyowera, M.C., Moss, R.H. (Eds.), Contribution of Working Group II to the Second Assessment of the Intergovernmental Panel on Climate Change. Cambridge University Press, Cambridge.

IPCC, 2001. Climate Change 2001: Synthesis Report. Contribution of Working Group I, II and II to the Third Assessment Report of the Intergovernmental Panel on Climate Change. Cambridge University Press, Cambridge, UK, New York, USA.

IPCC, 2005. In: Metz, B., Davidson, H.C.d.C.O., Loos, M., Meyer, L.A. (Eds.), IPCC Special Report on Carbon Dioxide Capture and Storage. B. Prepared by Working Group III of the Intergovernmental Panel on Climate Change. Intergovernmental Panel on Climate Change.

Itaoka, K., Saito, A., Akai, M., 2004. Public acceptance of $\mathrm{CO}_{2}$ capture and storage technology: a survey of public opinion to explore influential factors. Seventh International Conference on Greenhouse Gas Control Technologies (GHGT-7), Vancouver, Canada.

Itaoka, K., Saito, A., Akai, M., 2006. A path analysis for public survey data on social acceptance of $\mathrm{CO}_{2}$ capture and storage technology. Eighth International Conference on Greenhouse Gas Control Technologies (GHGT-8), Trondheim, Norway.

Kaldellis, J.K., 2005. Social attitude towards wind energy applications in Greece. Energy Policy 33 (5), 595-602.

Mander, S., Gough, C., 2006. Media framing of new technology: the case of carbon capture and storage. Eighth International Conference on Greenhouse Gas Control Technologies (GHGT-8), Trondheim, Norway.

Nisbet, M.C., Scheufele, D.A., 2002. Knowledge, reservations, or promise? A media effects model for public perceptions of science and technology. Communication Research 29 (5), 584-608.

OCAP, 2004. Milieuwinst in de glastuinbouw, Organic Carbon dioxide for Assimilation of Plants VOF, Westland (Netherlands).

OECD, I., 2001. Nuclear Power in the OECD. International Energy Agency (IEA)/Organisation for Economic Co-operation and Development (OECD), Paris, France.

OECD, I., 2003. Technology Innovation, Development and Diffusion. Organisation for Economic Co-operation and Development/International Energy Agency, Paris.

Palmgren, C.R., Morgan, M.G., BruinedeBruin, W., Keith, D.W., 2004. Initial public perceptions of deep geological and oceanic disposal of carbon dioxide. Environmental Science \& Technology 38 (24), 6441-6450.

Pickett, S.E., 2002. Japan's nuclear energy policy: from firm commitment to difficult dilemma addressing growing stocks of plutonium, program delays, domestic opposition and international pressure. Energy Policy 30 (15), 1337-1355.

PWC, D.S. Consultancy and Ecofys, 2001. Eindrapportage 'Schoon Fossiel', 'Laten we samen de eerste stapjes zetten'. PriceWaterhouseCoopers NV, Utrecht, The Netherlands.

Reiner, D., Curry, T., de Figueiredo, M., Herzog, H., Ansolabehere, S., Itaoka, K., Akai, K., Johnsson, F., Odenberger, M., 2006. An international comparison of public attitudes towards carbon capture and storage technologies. Eighth International Conference on Greenhouse Gas Control Technologies (GHGT-8), Trondheim, Norway. 
Ryan, C., 1991. Prime Time Activism: Media Strategies for Grassroots Organizing. Boston.

Scheufele, D.A., Lewenstein, B.V., 2005. The public and nanotechnology: how citizens make sense of emerging technologies. Journal of Nanoparticle Research 7, 659-667.

Shackley, S., McLachlan, C., Gough, C., 2004. The Public Perceptions of Carbon Capture and Storage. Tyndall Centre for Climate Change Research, Manchester.

Shackley, S., Mander, S., Reiche, A., 2006. Public perceptions of underground coal gasification in the United Kingdom. Energy Policy 34 (18), 3423-3433.

Sharp, J., Jaccard, M., Keith, D., 2006. Public attitudes toward geological disposal of carbon dioxide in Canada. Eighth International Conference on Greenhouse Gas Control Technologies (GHGT-8), Trondheim, Norway.

Siegrist, M., 2000. The influence of trust and perceptions of risks and benefits on the acceptance of gene technology. Risk Analysis 20, 195-204.

Surrey, J., Huggett, C., 1976. Opposition to nuclear power: a review of international experience. Energy Policy 4 (4), 286-307.

Ten Eyck, T.A., 2005. The media and public opinion on genetics and biotechnology: mirrors, windows, or walls? Public Understanding of Science 14, 305-316.

Terwel, B., Harinck, F., Ellemers, N., Daamen, D., 2006. Just say what they expect you to say: the influence of argumentation on trust in organizations. Eighth International Conference on Greenhouse Gas Control Technologies (GHGT-8), Trondheim, Norway.

$\mathrm{TNO} / \mathrm{RGD}, 1996$. Inventarisatie van mogelijkheden voor $\mathrm{CO}_{2}$-opslag in de Nederlandse ondergrond, Rijks Geologische Dienst (RGD); TNO Grondwater en Geo-Energie, Haarlem (Netherlands).

Turkenburg, W.C., Blok, K., Hendriks, C.A., Steinberg, M., 1992. Proceedings of the First International Conference on Carbon Dioxide Removal, Amsterdam. Pergamon Press, Oxford.

UN, 1997. Kyoto Protocol to the United Nations Framework Convention on Climate Change, United Nations.

van de Herik, C.W., 1998. Groups Support for Policy Making. Delft University of Technology, Delft.

van der Pligt, J., 1992. Nuclear Energy and the Public. Blackwell Scientific, Boston.

van Voorst tot Voorst, Q., 2005. Societal Acceptance of Carbon Dioxide Sequestration in the Netherlands. Department of Innovation Studies, Utrecht University, Utrecht.

VROM, 1999. Uitvoeringsnota Klimaatbeleid, Ministry of Housing, Spatial planning, and Environment, The Hague.

Wynne, B., 1996. May the sheep safely graze? A reflexive view of the expert-lay knowledge divide. In: Lash, S., Szerszynsky, B., Wynne, B. (Eds.), Risk, Environment and Modernity: Towards a New Ecology. Sage, London, pp. 165-198.

Zaller, J., 1992. The Nature and Origins of Mass Opinion. Cambridge, UK. 